\title{
KESALAHAN BERBAHASA DALAM KARANGAN DESKRIPSI SISWA SEKOLAH DASAR
}

\author{
Suryati \\ SDN Pengangsalan II Kalitengah Lamongan \\ Telp. 081332200909 \\ email : Suryatispd26@gmail.com
}

\begin{abstract}
Abstrak : Penelitian ini dilaksanakan dengan tujuan untuk mendeskripsikan kesalahan berbahasa dalam karangan deskripsi siswa kelas $V$ sekolah dasar. Data penelitian ini bersumber dari karangan deskripsi siswa kelas V SDN Pengangsalan II Kalitengah Lamongan. Data dikumpulkan dengan metode dokumentasi, metode simak dan metode catat. Hasil penelitian menunjukkan adanya kesalahan penggunaan ejaan, yang meliputi kesalahan pemakaian huruf kapital, tanda baca, penulisan kata ulang, penulisan kata depan dan penulisan kata keterangan sebab. Selain itu juga terdapat kesalahan dalam pemilihan kata yang meliputi pemilihan kata yang bersinonim, kesalahan pemakaian kata penghubung yang berpasangan dan kesalahan dalam pemilihan kata tugas, serta terdapat kesalahan dalam penyusunan kalimat yang meliputi ketidakcermatan penggunaan kata, ketidaklogisan dan ketidakhematan penggunaan kata.
\end{abstract}

Kata-Kata Kunci: Kesalahan Berbahasa, Karangan Deskripsi Siswa.

Abstract: The aim of this research was to describe the Speak Errors in Desciptive Essay of Fifth Grade Students of Elementary School. The data of this research was Desciptive Essay of Fifth Grade Students SDN Pengangsalan II Kalitengah Lamongan. To collect the data, this research used three techniques, namely : documentation technique, refer technique, and noted technique. The result of this research there are some errors, which include : spelling errors, namely : capital letter usage errors, punctuation usage errors, it consists of dot usage errors and comma usage errors, repetition words writing errors, preposition writing errors, conjunction usage errors, and adverb of cause writing errors. Besides that, there are diction errors namely: synonim words usage error, conjunctive pairs usage error, and task word usage error. There are some sentence structure errors, namely : carelessness of words usage, incoherence, and indiscretion of words usage.

Keywords: Speak Errors, Desciptive Essay of Students.

\section{PENDAHULUAN}

Hakikat belajar bahasa adalah belajar komunikasi. Oleh karena itu, pelajaran bahasa Indonesia diarahkan untuk meningkatkan kemampuan siswa dalam berkomunikasi dengan bahasa Indonesia baik secara lisan maupun tulisan. Pembelajaran bahasa juga bertujuan untuk mencapai kemampuan berbahasa : menyimak, berbicara, membaca dan menulis. Namun, kenyataan menunjukkan bahwa hasil pembelajaran menulis sampai saat ini masih memprihatinkan. Berbagai penelitian mendukung pernyataan tersebut. Intan Wirastuti (2013) 
menyatakan bahwa penulisan latar belakang skripsi dilakukan oleh mahasiswa non bahasa dan sastra Indonesia banyak kesalahan terutama pada penggunaan ejaan. Niken Kurniasari (2012) berdasarkan hahis penelitiannya, Niken menyatakan bahwa siswa SD kelas IV masih belum mampu menyusun karangan narasi dengan menggunakan ejaan yang benar.

Rendahnya keterampilan menulis tersebut dapat dimaklumi karena diantara keempat keterampilan berbahasa, keterampilan menulis menulis merupakan keterampilan berbahasa yang paling sulit (Suwandi, 2008:161) dan merupakan kemampuan paling luar dan kompleks (Dixon \& Nessel, 1983:83) dan paling sulit diajarkan (Farris, 1993:180).

Kemampuan menulis merupakan kemampuan dasar yang diutamakan dalam pendidikan formal sehingga harus dimiliki siswa pada semua jenjang sebab sebagian besar tugas belajar diberikan dalam bentuk tulisan. Dengan menyadari pentingnya kemampuan menulis, sudah selayaknya pembinaan kemampuan menulis diupayakan untuk ditingkatkan oleh berbagai pihak dalam masyarakat terutama pendidikan formal yang merupakan lembaga pendidikan yang secara intensif membina dan mengembangkan kemampuan menulis siswa.

Paparan di atas menunjukkan bahwa hasil pembelajaran menulis terutama yang terkait dengan kebahasaan sampai saat ini masih memprihatinkan. Namun, tidak berarti siswa tidak memiliki kemampuan menulis dan kemampuan menulis siswa tidak dapat dioptimalkan. Peneliti yakin bahwa dalam diri siswa terdapat kemampuan menulis yang dapat dioptimalkan. Untuk mengoptimalkan kemampuan menulis tersebut, perlu diketahui kesalahankesalahan yang sering dibuat siswa. Kesalahan yang sering dibuat siswa dalam menulis adalah kesalahan berbahasa. Karena itu, peneliti tertarik untuk mengungkap kesalahan berbahasa yang sering dilakukan siswa.

Menurut Syafi'i (dalam Ghufron, 1984:102) kesalahan berbahasa adalah pemakaian unit-unit kebahasaan yang meliputi bentukan kata, kalimat, paragraf serta pemakaian ejaan dan tanda baca yang melanggar kaidah-kaidah bahasa. Jika yang dimaksud bahasa itu adalah bahasa Indonesia, kaidah itu hanya kaidah bahasa Indonesia baku serta sistem ejaan dan tanda baca yang telah ditetapkan sebagaimana tersebut dalam buku Pedoman Ejaan Yang Disempurnakan. Adapun kaidah-kaidah yang digunakan sebagai tanda acuan dan menentukan kriteria kesalahan berbahasa diperbuat oleh pemakai bahasa Indonesia adalah kaidah bahasa Indonesia dalam ragam pemakaian bahasa Indonesia baku.

Ejaan adalah seperangkat aturan atau kaidah perlambangan bunyi bahasa, pemisahan, penggabungan, dan penulisannya dalam suatu bahasa (Finoza, 2002:13).

Pilihan kata atau diksi adalah hasil dari upaya memilih kata tertentu untuk dipakai dalam suatu turunan bahasa (Keraf, 2010:60).

Kalimat efektif adalah kalimat yang dapat mengungkapkan gagasan penutur atau penulisnya secara tepat sehingga dapat dipahami oleh pendengar atau pembaca secara tepat pula (Finoza, 2002:128).

Bentuk tulisan yang baik adalah tulisan yang memperhatikan penggunaan ejaan, pilihan kata, dan penyusunan kalimat yang baik. Maka, berdasarkan paparan di atas perlu adanya penelitian yang bertujuan untuk (1) mendeskripsikan kesalahan ejaan dalam karangan deskripsi siswa sekolah dasar, (2) mendeskripiskan kesalahan pemilihan kata dalam karangan deskripsi siswa 
sekolah dasar, dan (3) mendeskripsikan kesalahan penyusunan kalimat.

\section{METODE PENELITIAN}

Penelitian ini dirancang dalam bentuk penelitian deskriptif kualitatif yang disesuaikan dengan keperluan penelitian liguistik. Data utama dalam penelitian ini berupa karangan deskripsi siswa sekolah dasar. Sumber data penelitian ini adalah siswa sekolah dasar kelas V SDN Pengangsalan II Kalitengah Lamongan.

Untuk mengumpulkan data dalam penelitian ini digunakan teknik dokumentasi, teknik simak dan teknik catat. Teknik dokumentasi digunakan untuk mengambil arsip karangan siswa, teknik simak digunakan untuk menyimak menggunaan bahasa, dan teknik catat digunakan untuk mencatat hasil penyimakan data pada kartu data.

Dalam kegiatan menganalisis data penelitian ini dilakukan beberapa tahap: seleksi data, kodifikasi data, membaca data, mengidentifikasi, mengklasifikasi, merevisi, dan menyimpulkan data. Adapun langkah-langkah konkrit analisis data dalam penelitian ini direalisasi dalam dalam langkah-langkah berikut : (1) menyeleksi semua karangan siswa, (2) memberi kode pada karangan siswa, (3) membaca semua karangan siswa, (4) mengidentifikasi kesalahan berbahasa dalam karangan, (5) mengklasifikasi kesalahan berbahasa dalam karangan siswa, (6) merevisi kesalahan berbahasa, (7) mengumpulkan kesalahan berbahasa dalam karangan siswa.

\section{HASIL PENELITIAN}

\section{Kesalahan Ejaan dalam Karangan} Deksripsi Siswa Kelas V

Terdapat beberapa kesalahan ejaan dalam karangan deskripsi siswa. Kesalahan-kesalahan yang dimaksud terkait dengan pemakaian huruf kapital, tanda baca, penulisan kata ulang, penulisan kata depan, dan penulisan kata keterangan sebab.

\section{Kesalahan Pemakaian Huruf Kapital}

Dalam penelitian ini ditemukan beberapa kesalahan pemakaian huruf kapital dalam karangan siswa. Kesalahankesalahan itu adalah huruf kapital tidak dipakai sebagai unsur pertama kata awal kalimat, nama hari, judul karangan, nama geografi dan huruf kapital dipakai di tengah kalimat.

\section{Huruf Kapital Tidak Dipakai sebagai} Unsur Pertama Kata pada Awal Kalimat

Di dalam Pedoman Umum Ejaan Bahasa Indonesia Yang Disempurnakan, huruf kapital dipakai sebagai huruf pertama kata awal kalimat. Namun, dalam penelitian ini ditemukan huruf kapital tidak dipakai sebagai huruf pertama pada awal kalimat. Berikut contoh datanya.

setiap hari minggu ibu ${ }^{I I}$ para siswa wajib kerja bakti sesuai yang telah dijadwalkan. (ACS/1)

ada pohon mangga, jambu, pepaya semua dijaga dan dirawat denga baik. (CEM/1)

mereka menghiasi tempat sampah yang dicat dan lapangan yang indah. (MAA/1)

rontokan Daun berada di Jalan-jalan selalu dibersihkan. (SA/1)

di depan kelas terdapat banyak bungabunga. $(S E P / 1)$

\section{Huruf Kapital Dipakai pada Pertengahan Kalimat}

Pada pertengahan kalimat tidak dibenarkan menggunakan huruf kapital kecuali nama orang, hari, geografi, judul buku, kitab suci, dan judul karangan. Dalam penelitian ini ditemukan pemakaian huruf kapital pada pertengahan kalimat. Berikut contoh datanya.

Di halaman Sekolah Banyak ditanami tanaman-tanaman dan bunga-bunga. (AFR/1)

Di sebelah utara desaku Ada sungai Bengawan Solo. (FZ/1) 
Tanaman di desaku Indah dan Banyak hingga udaranya segar. (FZ/1)

Setiap hari Kami mendapat giliran untuk melaksanakan Piket. (MIZ/1a)

\section{Pemakaian Huruf pada Nama Hari}

Huruf kapital dipakai sebagai huruf pertama nama hari, namun dalam penelitian ini ditemukan nama hari ditulis dengan huruf kecil bukan dengan huruf kapital. Berikut contoh datanya.

Setiap hari minggu warga melakukan kerja bakti. (AYA/1)

Pada hari sabtu semua siswa membawa peralatan untuk membersihkan sekolah $(C E M / 1)$

\section{Pemakaian Huruf Kapital pada Nama Geografi}

Huruf kapital dipakai sebagai huruf pertama nama nama khas dalam geografi. Berikut ini contoh kesalahan siswa dalam pemakaian huruf kapital pada nama geografi.

Selain itu sekolahanku mewakili Kalitengah untuk perkemahan ke waduk gondang. (MRS/1)

Sekolahanku berada di desa pengangsalan kecamatan Kalitengah. $(S E P / 1)$

\section{Kesalahan Pemakaian Tanda Baca}

Dalam penelitian ini ditemukan kesalahan pemakaian tanda baca titik dan koma.

\section{Kesalahan Pemakaian Tanda Titik}

Kesalahan pemakaian tanda titik yang ditemukan dalam penelitian ini ada pada (1) tanda titik tidak dipakai pada akhir kalimat, (2) tanda titik dipakai di tengah kalimat, dan (3) tanda titik dipakai pada judul kalimat.

Tanda Titik tidak Dipakai pada Akhir Kalimat

Di dalam Pedoman Umum Ejaan Bahasa Indonesia Yang Disempurnakan tanda titik dipakai pada akhir kalimat yang bukan pertanyaan atau seruan.
Namun, pada penelitian ini ditemukan tanda titik tidak dipakai pada akhir kalimat. Berikut contoh datanya.

Agar tanaman-tanaman dan bunga-bunga tidak layu $(A F R / 1)$

Di sekolahku banyak tumbuhan ${ }^{I I}$ yang asri dan indah (ACS/1)

Lingkungan yang bersih pasti terhindari dari penyakit (SA/1)

di depan kelas terdapat banyak bungabunga (SEP/1)

Ada tumbuh-tumbuhan yang hijau dan rindang $(V N E P / 1)$

\section{Tanda Titik Dipakai di Tengah Kalimat}

Dalam pertengahan kalimat tidak boleh menggunakan tanda titik. Kesalahan pemakaian tanda titik di tengah kalimat dapat dilihat pada data berikut:

Sungguh tak terbayangkan. karena di dalam pot terdapat banyak cacing (MFHd/1)

Lingkungan seperti ini. haruslah dicontoh oleh desa lain (SA/1)

\section{Tanda Titik Dipakai pada Judul Kalimat}

Judul karangan tidak memakai tanda baca apapun. Namun, dalam penelitian ini ditemukan tanda titik dipakai pada judul karangan. Berikut datanga :

Lingkungan Sekolah. (DER/1)

Lingkungan Desa. (EANS/1)

\section{Kesalahan Pemakaian Tanda Koma}

Tanda koma dipakai diantara unsurunsur dalam suatu pemerian atau pembilang. Kesalahan siswa dalam pemakaian tanda koma bisa dilihat pada data berikut.

ada yang menyirami bunga menyirami tanaman Menyapu dan memberi pupuk pada bunga-bunga dan tanaman-tanaman (AFR/1)

Di sana juga banyak bunga II antara lain kamboja pucuk merah eqorbia palm dan masih banyak lagi. (ACS/1) 
Ada yang menyapu halaman menyiram bunga membuang sampah ke Tempat pembuangan sampah. (ACS/1)

Ada banyak pohon seperti pohon mangga jambu dan jeruk. (VNFP/1)

\section{Penulisan Kata Ulang}

Bentuk ulang harus ditulis secara lengkap dengan menggunakan tanda hubung. Kesalahan siswa dalam penulisan kata ulang bisa dilihat pada data berikut.

Di sekolahanku banyak tumbuhan ${ }^{I I}$ yang asri dan indah (ACS/1)

Lingkungan yang bersih adalah impian semua orang termasuk siswa ${ }^{I I} d i$ sekolahku. (ACS/1)

Semua tanaman ${ }^{2}$ dan bunga ${ }^{2}$ selalu kami siram dan rawat setiap hari. (MIZ/1)

Saya dan teman ${ }^{x x}$ sangat senang bermain di halaman sekolah karena bersih dan rindang. (VNFP/1)

\section{Penulisan Kata Depan}

Menurut Ghufron (2015:103) kata depan di-, ke-, dari ditulis terpisah dari kata yang mengikutinya, kecuali di dalam gabungan kata yang sudah dianggap sebagai satu kata. Kesalahan siswa dalam penulisan kata depan bisa dilihat pada contoh data berikut.

Pada saat itu didesaku sedang mengikuti lomba LGC. (EANS/1)

Disebelah utara desaku Ada sungai Bengawan Solo. (FZ/1)

Disetiap kelas ada tempat sampah. (MAA/1)

Dikelasku ruangannya sangat bersih dan juga rapi. (MRS/1)

\section{Penulisan Kata Keterangan Sebab}

Di dalam penelitian ini ditemukan penulisan kata keterangan tidak baku. Berikut datanya.

Kalo hujan lingkungan kelas maupun ruang kelas sangat kotor. (ZT/1)

Di sekolah banyak pohon mangga dan kalo bunganya pucuk merah. (ZT/1)
Murid kalo membuang sampah sembarangan. (ZT/1)

\section{Kesalahan Pemilihan Kata}

Dalam penelitian ini ditemukan beberapa kesalahan dalam pemilihan kata. Kesalahan-kesalahan yang dimaksud adalah kesalahan pada pemilihan kata bersinonim, kesalahan pemakaian kata penghubung yang berpasangan dan kesalahan dalam pemilihan kata tugas.

\section{Kesalahan pada Pemilihan Kata Bersinonim}

Menuruf Keraf (2010:89) salah satu syarat ketepatan diksi adalah mampu membedakan dengan cermat kata-kata yang hampir bersinonim. Kesalahan siswa pada pemilihan kata bersinonim dapat dilihat pada data berikut :

Tumbuhan yang sudah meninggal akan dibuang dan diganti dengan pohon baru. (CEM/2)

Sekarang sekolahku menjadi cantik dan sejuk. $(C E M / 2)$

Tapi meskipun begitu masih banyak bunga yang layu atau meninggal. (ZT/2)

\section{Kesalahan Pemakaian Kata Penghubung yang Berpasangan \\ Kesalahan pemakaian kata penghubung yang berpasangan dapat dilihat pada data.}

Karena tidak ada tumbuhan, sehingga anak-anak merasa tidak nyaman berada di lapangan. (AZIF/2)

\section{Kesalahan dalam Pemilihan Kata Tugas}

Dalam penelitian ini kesalahan dalam pemilihan kata tugas bisa dilihat pada data berikut.

Tidak lupa bersalaman kepada guruguru. (NPS/2)

\section{Kesalahan Penyusunan Kalimat}

Pada penelitian ini ditemukan beberapa kesalahan penyusunan kalimat 
yaitu ketidakhematan penggunaan kata, ketidaklogisan, dan ketidakcermatan penggunaan kata.

\section{Ketidakhematan Penggunaan Kata}

Kalimat tidak hemat atau kalimat yang mubazir adalah kalimat yang menggunakan dua bentuk yang maknanya sama. Kalimat efektif memenuhi azas kehematan atau tidak mengandung unsur mubazir. Dalam penelitian ini ditemukan ketidakhematan penggunaan kata. Ketidakhematan penggunaan kata itu bisa dilihat pada contoh data berikut.

Di depan kelas terdapat banyak bungabunga. (SEP/3)

Di desa Pengangsalan banyak rumahrumah warga. (NPS/3)

Di sekolahku banyak tumbuhan ${ }^{I I}$ yang asri dan indah. (ACS/3)

Semua tanaman ${ }^{2}$ dan bunga $^{2}$ selalu kami siram dan rawat setiap hari. (MIZ/3)

\section{Ketidaklogisan}

Kalimat tidak logis adalah kalimat yang maknanya tidak dapat diterima akal sehat. Dengan demikian, logis tidaknya kalimat ini dilihat dari segi makna yang disampaikan. Ketidaklogisan kalimat dalam penelitian ini bisa dilihat dari data berikut.

Maka sekolahku sering diadakan dalam

lomba penilaian setiap tahunnya. (DER/3)

Di desaku setetangga sangat rukun. (NPS/3)

Sungai di depan sekolah juga banyak sampah berserakan. (ZT/3)

\section{Ketidakcermatan Penggunaan Kata}

Kalimat tidak cermat adalah kalimat yang pilihan katanya, penulisan atau pelafalannya tidak cermat. Ketidakcermatan penggunaan kata dalam penelitian ini bisa dilihat dari data berikut.

Tidak lupa bersalaman kepada guruguru. (MRS/3)
Sehabis itu saya dan teman-teman makan bersama. (MRS/3)

Lingkungan di sekitarku sangatlah bersih dan ramah. (SA/3)

\section{PEMBAHASAN}

Temuan penelitian menunjukkan adanya beberapa kesalahan penggunaan ejaan dalam karangan deskripsi siswa SD. Pemakaian huruf kapital, tanda baca, penulisan kata ulang, penulisan kata depan dan penulisan kata keterangan sebab masih menunjukkan adanya kesalahan.

Kesalahan pemakaian huruf kapital antara lain huruf kapital tidak dipakai sebagai unsur pertama kata pada awal kalimat, nama hari, judul karangan, nama geografi dan huruf kapital dipakai di tengah kalimat. Huruf kapital tidak dipakai sebagai unsur pertama kata pada awal kalimat dalam karangan siswa SD. Ini merupakan penyimpangan dari kaidah bahasa. Dalam Pedoman Umum Ejaan Bahasa Indonesia Yang Disempurnakan, huruf kapital dipakai sebagai huruf pertama kata awal kalimat. Supaya tidak menyalahi kaidah bahasa maka setiap huruf pertama kata awal kalimat harus menggunakan huruf kapital tidak huruf kecil.

Kesalahan pemakaian huruf kapital pada nama hari, judul karangan, dan nama geografi juga banyak ditemukan dalam karangan deskripsi siswa SD. Hal ini juga merupakan menyimpangan dari kaidah bahasa, karena di dalam Pedoman Umum Ejaan Bahasa Indonesia Yang Disempurnakan, huruf kapital dipakai sebagai huruf pertama nama hari, judul karangan, dan nama geografi. Dalam penelitian ini ditemukan penulisan nama hari, judul karangan dan nama geografi menggunakan huruf kecil. Supaya tidak menyalahi kaidah bahasa maka huruf pertama nama hari, judul karangan, dan nama geografi seharusnya menggunakan huruf kapital. 
Kesalahan pemakaian tanda baca dalam penelitian ini meliputi pemakaian tanda titik dan tanda koma. Kesalahan pemakaian tanda titik paling sering dilakukan oleh siswa. Kesalahankesalahan tanda titik dalam penelitian ini yang sering dilakukan siswa adalah tanda titik tidak dipakai apda akhir kalimat. Ini merupakan penyimpangan dari kaidah bahasa. Di dalam Ejaan Yang Disempurnakan tanda titik dipakai pada akhir kalimat yang bukan pertanyaan atau seruan. Supaya tidak menyalahi kaidah bahasa seharusnya setiap akhir kalimat yang bukan pertanyaan atau seruan memakai tanda titik.

Kesalahan penulisan kata ulang juga banyak ditemukan dalam karangan deskriptif siswa SD. Kesalahan penulisan kata ulang terjadi karena siswa memakai angka atau simbol untuk menulis kata ulang. Dalam Ejaan Yang Disempurnakan, bentuk ulang ditulis secara lengkap dengan menggunakan tanda hubung.

Kesalahan penulisan kata depan juga ditemukan dalam karangan siswa SD. Kesalahan penulisan kata depan terjadi karena siswa merangkai kata dengan dengan kata yang mengikutinya. Menurut Ghufron (2015:103) kata depan di-, ke-, dari ditulis terpisah dari kata yang mengikutinya, kecuali di dalam gabungan kata yang sudah dianggap satu kata.

Kesalahan pemilihan kata juga ditemukan dalam karangan siswa SD. Kesalahan pemilihan kata ini meliputi kesalahan pada pemilihan kata yang bersinonim, kesalahan pemakaian kata penghubung yang berpasangan dan kesalahan dalam pemilihan kata tugas.

Kesalahan pada pemilihan kata yang bersinonim terjadi karena siswa menggunakan kata meninggal dan cantik untuk tumbuhan. Penggunaan kata meninggal dan cantik kurang tepat karena tidak lazim tumbuhan itu meninggal atau tumbuhan itu cantik. Yang tepat adalah menggunakan kata mati dan indah. Jadi kata meninggal harus diubah dengan kata mati, karena kata mati digunakan dengan pengertian yang netral dan tidak bernilai rasa hormat. Kata meninggal bernilai rasa hormat, oleh sebab itu hanya digunakan untuk manusia.

Kesalahan penyusunan kalimat dalam penelitian ini meliputi ketidakhematan penggunaan kata, ketidaklogisan dan ketidakcermatan penggunaan kata.

Ketidakhematan penggunaan kata yang dilakukan siswa SD karena pemakaian kata banyak dan semua diikuti dengan kata ulang. Menurut Setyawati (2003:74) dalam sebuah kalimat untuk penanda jamak sebuah kata, cukup menggunakan satu penanda saja. Jika sudah terdapat penanda jamak tidak perlu kata tersebut diulang atau jika sudah diulang tidak perlu menggunakan penanda jamak. Penulisan yang benar apabila menggunakan kata banyak atau semua, maka tidak diikuti kata ulang, dan apabila tidak menggunakan kata banyak atau semua, maka bisa menggunakan kata ulang. Apabila keduanya digunakan secara bersamasama, salah satunya menjadi mubazir.

\section{PENUTUP}

\section{Simpulan}

Berdasarkan hasil analisa penelitian tentang kesalahan berbahasa dalam karangan deskripsi siswa kelas V SDN Pengangsalan II Kalitengah Lamongan dapat disimpulkan sebagai berikut.

Dari analisis data pada karangan siswa di atas, ditemukan beberapa kesalahan penulisan ejaan. Kesalahankesalahan tersebut diantaranya yaitu: (1) kesalahan pemakaian huruf kapital, yang meliputi : huruf kapital tidak dipakai 
sebagai unsur pertama kata pada awal kalimat, huruf kapital dipakai di tengah kalimat, huruf kapital tidak dipakai pada nama hari, huruf kapital tidak dipakai pada judul karangan dan nama geografi; (2) Pemakaian Tanda Baca, yaitu : (a) kesalahan pemakaian tanda titik, yang meliputi : tanda titik tidak dipakai pada akhir kalimat, tanda titik dipakai di tengah kalimat, dan tanda titik dipakai pada judul karangan; (b) kesalahan pemakaian tanda koma; (3) kesalahan penulisan kata ulang; (4) kesalahan penulisan kata depan; (5) Kesalahan penggunaan kata sambung; dan (6) kesalahan penulisan kata keterangan sebab.

Kesalahan pemilihan kata dalam karangan deskripsi siswa kelas V SDN Pengangsalan II Kalitengah Lamongan ditemukan beberapa kesalahan, yaitu : (1) pemilihan kata yang bersinonim, (2) kesalahan pemakaian kata penghubung yang berpasangan, dan (3) kesalahan dalam pemilihan kata tugas.

Kesalahan penyusunan kalimat dalam karangan deskripsi siswa kelas $\mathrm{V}$ SDN Pengangsalan II Kalitengah Lamongan yang ditemukan ialah : (1) ketidakhematan penggunaan kata, (2) ketidaklogisan, dan (3) ketidakcermatan penggunaan kata.

Saran

Berdasarkan simpulan tersebut, pada bagian ini disampaikan beberapa saran yang dapat dijadikan bahan pertimbangn oleh pihak-pihak yang terkait secara langsung dengan penulisan ini.

Banyak ditemukan kesalahankesalahan dalam penulisan karangan deskripsi, misalnya : kesalahan ejaan, kesalahan pemilihan kata dan kesalahan pembentukan kalimat. Oleh karena itu, sebelum mengajarkan menulis karangan deskripsi pada siswa, guru hendaknya mengoptimalkan penyampaian penulisan ejaan dengan benar.
Selain hal di atas, guru atau pengajar harus lebih cermat lagi dalam mengajarkan menulis karangan. Guru harus lebih mengutamakan pemberian contoh, arahan dan praktik menulis karangan secara langsung. Hal ini tentunya akan lebih memahamkan siswa dari pada hanya bersifat menyimak materi.

Bagi siswa, apabila dalam menulis karangan ada hambatan atau kesulitan, siswa harus lebih aktif bertanya pada guru atau pengajar.

Bagi peneliti selanjutnya, penelitian ini hanya sebatas mendeskripsikan kesalahan-kesalahan berbahasa dalam penulisan karangan. Peneliti selanjutnya dapat mengembangkan penelitian ini secara lebih mendalam lagi, misalnya ke penelitian eksperimen metode pembelajaran yang paling cocok dalam penulisan karangan deskripsi sehingga dapat meminimalisir kesalahan penulisan karangan.

\section{DAFTAR PUSTAKA}

Alwi, Hasan. 2003. Tata Bahasa Baku Bahasa Indonesia. Jakarta: PT. Rineka.

Arifin, Zaenal dan Hadi, Farid. 2008. 1001 Kesalahan Berbahasa. Jakarta: CV. Akademika Pressindo.

Arifin, Zaenal dan Tasai Amran, S. 2008. Cermat Berbahasa Indonesia. Jakarta: Akademia PKSSINDO.

Depdiknas. 2006. Pedoman Umum Ejaan Bahasa Indonesia Yang Disempurnakan dan Pedoman Umum Pembentukan Istilah. Bandung: Irama Widya.

Finoza, Lamuddir. 2002. Komposisi Bahasa Indonesia. Jakarta: Insan Mulia.

Ghufron, Syamsul, dan Sariban. 2016. Pedoman Penulisan Proposal, Tesis, dan Artikel Ilmiah. Lamongan: APPI-Bastra. 
Ghufron, Syamsul, dkk. 2011. Pengembangan Buku Ajar Bahasa Indonesia Berbasis Kesalahan Berbahasa pada Siswa Sekolah Dasar-Laporan Akhir Pelaksanaan Hibang Bersaing Tahun Anggaran 2011. Universitas Darul Ulum Lamongan.

Ghufron, Syamsul, dkk. 2015. Kesalahan Berbahasa: Teori dan Aplikasi. Yogyakarta: Ombak.

Harsanti. 2014. Analisis Kesalahan Berbahasa dalam Bidang Morfologi pada Karangan Siswa Kelas VII SMP Negeri Godong.

Ikawati. 2013. Analisis Penggunaan Kosakata pada Karangan Narasi Siswa yang Berlatar Belakang Bahasa Betawi Kelas VII MTs Negeri Parung Semester Genap Tahun Pelajaran 2012/2013. Skripsi Program Studi Bahasa dan Sastra Indonesia Fakultas Ilmu Tarbiyah dan Keguruan UIN Syarif Hidayatullah Jakarta.

Jauhari, Heri. 2013. Terampil Mengarang. Bandung: Nuansa Cendekia.

Keraf, Gorys. 1984. Tata Bahasa Indonesia. Jakarta: Penerbit Nusa Indah.

Keraf, Gorys. 2010. Diksi dan Gaya Bahasa. Jakarta: PT. Ikrar Mandiri Abadi.

Khoiruddin, Alang. 2014. Buku Pintar Bahasa Indonesia. Lamongan: CV. Pustaka Ilalang.

Kurniasari, Niken. 2012. Analisis Kesalahan Berbahasa Indonesia dalam Karangan pada Siswa Kelas IV SDN Bumiayu 01 Kecamatan Kedungkandang Malang. Skripsi Program Studi Pendidikan Guru Sekolah Dasar Jurusan Kependidikan Sekolah Dasar dan Prasekolah Fakultas Ilmu
Pendidikan Universitas Negeri Malang.

Mahsun. 2005. Metode Penelitian Bahasa Edisi Revisi. Jakarta: PT. Raja Pers.

Maliki, Imam. 1999. Pembinaan Bahasa dan Sastra Indonesia. Surabaya: Udaha Nasional.

Moloeng, Lexy. 2009. Metode Penelitian Kualitatif. Bandung: PT. Remaja Rusdakarya.

Muslich, Masnur. 2008. Fonologi Bahasa Indonesia. Jakarta: PT. Bumi Aksara.

Pusat Bahasa Departeman Pendidikan Nasional. 2009. Buku Praktis Bahasa Indonesia. Jakarta: Pusat Bahasa.

Puspitasari, Yeti. 2014. Analisis Kesalahan Huruf Kapital dan Tanda Baca pada Paragraf Deskripsi Siswa Kelas V SD Negeri Sampay Rumpin Bogor. Skripsi Program Studi Pendidikan Guru Sekolah Dasar Madrasah Ibtidaiyah (PGMI) Fakultas Ilmu Tarbiyah dan Keguruan UIN Hidayatullah Jakarta.

Ramlan, dkk. 1994. Bahasa Indonesia yang Salah dan yang Benar. Yogyakarta: Andi Offset Yogyakarta.

Ramlan, M. 2005. Sintaksis. Yogyakarta: CV. Karyono.

Setyawati, Nanik. 2013. Analisis Kesalahan Berbahasa Indonesia. Surakarta: Yuma Pustaka.

Tarigan, Henry Guntur dan Jaso Tarigan. 2008. Pengajaran Analisis Kesalahan Berbahasa. Bandung: Angkasa.

Tarigan, Henry Guntur. 2008. Menulis sebagai Suatu Keterampilan Berbahasa. Bandung: Angkasa. 
Tarigan, Henry Guntur. 2009. Pengajaran Remidi Bahasa.

Bandung: Angkasa.

Wirastuti, Intan. 2013. Analisis Kesalahan Berbahasa pada Penulisan Latar Belakang Skripsi Mahasiswa Non Bahasa dan Sastra Indonesia Universitas Muhammadiyah Surakarta. 